\title{
Analisis Kinerja Keuangan Perusahaan dengan Metode Economic Value Added (EVA) (Studi Kasus Perusahaan Otomotif Go Publik)
}

\author{
Rahman Mubarok \\ Alumni Departemen Manajemen Fakultas Ekonomi dan manajemen \\ Farida Ratna Dewi \\ Departemen Manajemen Fakultas Ekonomi dan Manajemen \\ Institut Pertanian Bogor \\ Rieda05@yahoo.com
}

\begin{abstract}
ABSTRAK
Global economics crisis causes the fall of world stock. This is causes weakens it share in BEI, including sector otomotif. BEI has some stock indexes as movement indicator of stock price, one of them is index Kompas 100. This Index represents of about 70-80 percent market capitalization value total of share in BEI. However, that can be different with other index, so that be necessary to measure of each corporate performance with using Economic Value Added (EVA) method. EVA is used to measure of corporate performance based of the value. value added will be create, if the retained earning more than cost of capital. From two company analized during the 2007 to 2008 period, there is only one of corporate have a performance increase at 2008, that is PT Multistrada Arah Sarana Tbk, this is mean the corporate has been investor expectation filled. Differ from PT Multistrada, PT Gajah Tunggal at 2008 have a performance decrease. At 2007 it have positive value of EVA, but at 2008 value of EVA get down to negative. This is happen cause of dead loss in consequence of global economics crisis. For the companies that give the negative value, it better find out more strategies so it can make their profit rise and also to push the capital cost with choosing the lowest capital structure. Beside that, the companies also should erase the activities that can caused the value of the company becoming less.
\end{abstract}

Keyword: Index kompas-100, Otomotif, Economic Value Added (EVA), Financial performance.

\section{Pendahuluan}

Industri otomotif di Indonesia mengalami perkembangan yang pesat dalam satu periode terakhir ini, sepanjang tahun 2008 pasar otomotif mengalami pertumbuhan hampir 40 persen. Pasar otomotif dalam negeri mengalami peningkatan penjualan sampai 39,3 persen menjadi 603.774 unit, hal ini merupakan peristiwa yang fenomenal dan tidak pernah terjadi di negara manapun. Pertumbuhan ini disebabkan adanya ketertarikan pengusaha kendaraan untuk menanamkan modal di negara Indonesia. Tidak hanya itu saja, hal ini juga didukung dengan adanya peningkatan permintaan 
kendaraan serba guna yang menjadi kontribusi terbesar atas peningkatan penjualan di Indonesia pada tahun 2008.

Pada akhir tahun 2008, industri otomotif di dunia mengalami keterpurukan akibat adanya krisis ekonomi global, yang diawali dengan terpuruknya saham raksasa otomotif di Amerika General Motor (GM) yang mengalami penurunan penjualan hampir 45 persen pada bulan Oktober dan pesaingnya Ford menderita penurunan penjualan hingga 30 persen pada periode yang sama. Perusahaan otomotif di Indonesia juga tak bisa lepas dari dampak krisis keuangan ini, penjualan yang merosot membuat banyak perusahaan mengalami kelebihan stok mobil.

Walaupun sektor otomotif terkena imbas dari krisis global, kinerja perusahaan masih menunjukkan performa yang positif. Laba operasinal group otomotif dan keuangan meningkat sebesar 46 persen menjadi Rp 3,42 triliun. Laba bersih PT Astra Internasional (ASII) melonjak 61 persen menjadi Rp 7,37 triliun, dan laba usaha naik 65 persen menjadi Rp 9,96 triliun, sedangkan PT Indomobil Sukses Internasional (IMAS) hingga bulan September, laba bersihnya tercatat Rp 95,150 miliar, meningkat tajam sebesar 1.041,84 persen dibandingkan periode yang sama tahun lalu sebesar $R p$ 8,333 miliar. Sedangkan pendapatan naik 65,42 persen mencapai Rp 5,795 triliun, dari sebelumnya Rp 3,503 triliun (www.inilah.com, 2009).

Terdapat 13 saham perusahaan otomotif yang terdaftar di Bursa Efek Indonesia yaitu, Astra International Tbk (ASII), Astra Otoparts Tbk (AUTO), Indo Kordsa Tbk (BRAM), Goodyear Indonesia Tbk (GDYR), Gajah Tunggal Tbk (GJTL), Indomobil Sukses International Tbk (IMAS), Indospring Tbk (INDS), Multi Prima Sejahtera Tbk (LPIN), Multistrada Arah Sarana Tbk (MASA), Nipress Tbk (NIPS), Prima Alloy Steel Tbk (PRAS), Selamat Sempurna Tbk (SMSM), Allbond Makmur Usaha Tbk (SQMI). BEI mempunyai beberapa indeks saham sebagai indikator pergerakan saham salah satunya adalah indeks kompas-100, (www.idx.co.id, 2009).

Indeks kompas 100 merupakan 100 saham yang dipilih harian kompas melalui beberapa kriteria. Saham-saham yang terpilih harus memiliki likuiditas yang tinggi, nilai kapitalisasi pasar yang besar, dan merupakan saham-saham yang memiliki fundamental dan kinerja yang baik. Terdapat dua saham perusahaan otomotif yang terpilih dan dimuat dalam indeks kompas 100 antara lain, PT Gajah Tunggal Tbk (GJTL) dan PT Multistrada Arah Sarana Tbk (MASA).

Saham-saham yang termasuk dalam Kompas-100 diperkirakan mewakili sekitar 7080 persen dari total nilai kapitalisasi pasar seluruh saham yang tercatat di BEI, dengan demikian investor bisa melihat kecenderungan arah pergerakan indeks dengan mengamati pergerakan indeks Kompas-100. Akan tetapi, ini bisa saja berlawanan arah dengan Indeks Harga Saham Gabungan (IHSG) maupun indeks lainnya. Tujuan utama BEI dalam menerbitkan indeks Kompas-100 ini adalah untuk menyebarluaskan informasi pasar modal kepada masyarakat umum serta menggairahkan masyarakat untuk mengambil manfaat dari keberadaan BEI, baik untuk investasi maupun mencari pendanaan bagi perusahaan dalam mengembangkan perekonomian nasional.

Supaya industri otomotif dapat bertahan dan terus berkembang pada lingkungan bisnis yang semakin kompetitif dan kompleks, perusahaan diharapkan dapat melipatgandakan kekayaan perusahaan. Untuk memenuhi harapan tersebut diperlukan kinerja manajemen yang efektif dan efisien, sehingga untuk mengetahui 
kinerja perusahaan otomotif mana yang efektif terlebih akibat adanya krisis keuangan global pada akhir tahun 2008 diperlukan adanya pengukuran kinerja masing-masing perusahaan agar investor mengetahui dengan jelas bagaimana keadaan perusahaannya.

Pendekatan untuk menilai kinerja perusahaan yang biasa dipakai adalah evaluasi atas laporan keuangan. Evaluasi ini meliputi pengukuran dengan melihat berbagai standar akuntansi seperti laba operasi, laba bersih dan aliran kas dari operasi. Hal ini menjadi pertimbangan yang sangat penting karena kondisi keuangan perusahaan, mencerminkan mampu tidaknya perusahaan memberikan tingkat pengembalian yang diharapkan.

Saat ini banyak perusahaan yang sudah mulai menggunakan Value Based Management (VBM) sebagai dasar pengukuran kinerjanya. VBM memiliki dua elemen penting yaitu penciptaan nilai bagi pemegang saham sebagai tujuan utama perusahaan dan VBM sebagai ukuran kinerja internal perusahaan sehingga dapat memotivasi manajemen untuk meningkatkan kinerjanya tersebut. Penerapan VBM dalam manajemen dapat mencerminkan kinerja dan prospek perusahaan di masa mendatang.

Salah satu alat pengukuran kinerja yang berdasarkan VBM adalah Economic Value Added (EVA). Adanya Economic Value Added (EVA) menjadi relevan untuk mengukur kinerja yang berdasarkan nilai (value) karena EVA yang merupakan suatu indikator mengenai adanya penciptaan nilai dari suatu investasi yang dilakukan oleh pemegang saham perusahaan. EVA yang dipopulerkan dan dipatenkan oleh Stewart \& Company ini menghitung economic profit dan bukan accounting profit. Pada dasarnya, EVA mengukur nilai tambah dalam suatu periode tertentu. Nilai tambah ini tercipta bila perusahaan memperoleh keuntungan (profit) di atas cost of capital perusahaan. Secara matematis EVA dihitung dari laba setelah pajak dikurangi dengan cost of capital tahunan. Jika EVA positif, menunjukkan perusahaan telah menciptakan kekayaan. Oleh karena itu metode EVA dapat menjadi alternatif penilaian kinerja keuangan perusahaan, karena salah satu hal yang menjadi pertimbangan investor dalam berinvestasi adalah kinerja perusahaan.

Investor akan selalu memperhatikan seberapa besar risiko yang dihadapi dan seberapa besar tingkat pengembalian yang dapat diharapkan dari investasi tersebut. Untuk itu para manajer harus bisa membujuk para investor untuk menanamkan modalnya dan meyakinkan investor bahwa dana yang ditanamkan akan lebih produktif dan menguntungkan bila ditanam pada perusahaan mereka. Dengan adanya metode EVA diharapkan dapat membantu para investor dalam memilih perusahaan otomotif mana yang dapat memberikan nilai bagi pemegang sahamnya.

Ruang lingkup dari penelitian ini adalah menganalisis kinerja keuangan perusahaan otomotif yang terpilih dalam indeks kompas 100 periode 2007-2008 dengan menggunakan Economic Value Added (EVA). -Perusahaan otomotif yang diteliti adalah dua perusahaan yang dimuat dalam indeks kompas 100 adalah PT Gajah Tunggal Tbk (GJTL), dan PT Multistrada Arah Sarana Tbk (MASA).

Berdasarkan uraian di atas, permasalahan dapat dirumuskan sebagai berikut:

1. Bagaimanakah kinerja keuangan perusahaan otomotif yang tercatat dalam indeks kompas-100? 
2. Apakah berinvestasi pada perusahaan otomotif menarik bagi investor?

Penelitian ini bertujuan untuk:

1. Mengevaluasi kinerja saham otomotif yang tercatat dalam indeks kompas-100 di BEI dengan menggunakan metode EVA.

2. Memberikan referensi bagi investor dalam berinvestasi pada saham-saham otomotif.

Penelitian ini diharapkan dapat memberikan manfaat untuk semua kalangan, khususnya para investor sebagai referensi dalam sebagai bahan pertimbangan ketika mengambil keputusan investasi di pasar modal. Sedangkan untuk para manajer sebagai tambahan informasi suatu alat pengukuran alternatif untuk menilai kinerja perusahaan maupun unit bisnis.

\section{Metode Penelitian}

\section{II.1. Kerangka Pemikiran}

EVA merupakan alat analisis untuk mengukur nilai tambah perusahaan dengan menghitung seluruh biaya modal, baik setoran modal yang berasal dari pemegang saham maupun dari pinjaman, atau risiko yang dihadapi perusahaan dalam melakukan investasi. Perusahaan yang akan diteliti adalah perusahaan-perusahaan otomotif yang telah tercatat di BEI dan terpilih dalam indeks kompas 100 periode 2007-2008. Saham-saham otomotif yang terpilih dalam indeks kompas 100 adalah PT Gajah Tunggal Tbk (GJTL) dan PT Multistrada Arah Sarana Tbk (MASA).

Untuk mengukur kinerja keuangan diperlukan data laporan keuangan berupa laporan laba-rugi dan neraca. Secara sederhana EVA dapat diketahui dari NOPAT dikurangi biaya modal. Net Operating After Taxes (NOPAT) merupakan laba bersih ditambah biaya bunga setelah pajak, sedangkan biaya modal (Cost Of Capital) menunjukkan besarnya kompensasi atau pengembalian modal yang dituntut oleh investor atas modal yang diinvestasikan di perusahaan. Modal (capital) berasal dari dua sumber dana yaitu ekuitas dan hutang. Nilai NOPAT dapat diperoleh dari laporan laba/rugi, sedangkan biaya modal dapat diperoleh dari neraca perusahaan.

Setelah diketahui nilai EVA, maka dapat dilihat kinerja perusahaan baik atau tidak. Nilai tersebut merupakan referensi bagi beberapa pihak yang berkepentingan, seperti manajer, investor serta stakeholder lainnya untuk mengambil keputusan.

\section{II.2. Lokasi dan Waktu Penelitian}

Penelitian ini dilaksanakan pada bulan Maret 2008 sampai dengan April 2008. Lokasi penelitian ini terdiri dari beberapa instansi publik yang terkait dengan penelitian yaitu: Bursa Efek Indonesia (BEI), Pusat Referensi Pasar Modal Bursa Efek Indonesia (PRPM-BEI) dan Bank Indonesia (BI).

Data yang digunakan dalam penelitian ini adalah data sekunder yang bersifat kualitatif dan kuantitatif dari periode Januari 2007 sampai Desember 2008. Data sekunder yang digunakan dalam penelitian ini adalah berupa laporan keuangan dan gambaran umum perusahaan otomotif yang tercatat di indeks kompas 100 periode 2007-2008, data bulanan indeks harga saham masing-masing perusahaan yang terdaftar di BEI, Indeks Harga Saham Gabungan (IHSG) bulanan dari tahun 2007 hingga 
2008, tingkat suku bunga Sertifikat Bank Indonesia (SBI) per satu bulanan dari tahun 2007 sampai 2008. Sebagai data penunjang yang digunakan adalah data yang relevan dengan penelitian yang diperoleh dari literatur, koran, jurnal, majalah, laporan penelitian, dan media elektronik.

\section{II.3. Pengolahan dan Analisis Data}

Pengolahan data dilakukan setelah data di lapangan terkumpul. Menurut Nazir (2005), analisis data merupakan bagian yang sangat penting dalam metode ilmiah, karena dengan analisislah data tersebut dapat diberi arti dan makna yang berguna dalam memecahkan masalah penelitian. Pengolahan data dilakukan dengan menggunakan kalkulator dan perangkat lunak Ms Excel 2003. Alat analisis yang digunakan dalam mengolah data dalam penelitian ini adalah analisis Economic Value Added (EVA).

Langkah-langkah dalam perhitungan analisis EVA adalah sebagai berikut :

1. Menghitung tingkat pengembalian dari masing-masing saham yang didefinisikan sebagai rata-rata dari keuntungan modal yaitu selisih antara harga saham bulan ini dengan harga saham bulan sebelumnya. Rumusnya adalah:

$$
R_{i t}=\frac{P_{i t}-P_{i t-1}+D_{t}}{P_{i t-I}}
$$

Di mana:

$\mathrm{R}_{\text {it }} \quad$ = Tingkat pengembalian saham perusahaan bulan ke-t

$\mathrm{P}_{\text {it }} \quad$ = Harga saham perusahaan perlembar bulan ke-t

$\mathrm{P}_{\mathrm{it}-1}=$ Harga saham perusahaan perlembar bulan ke-t-1

$D_{t} \quad=$ Deviden pada bulan ke- $t$

2. Menghitung tingkat pengembalian pasar bulanan dan tingkat pengembalian ratarata pasar. Rumusnya adalah:

$$
\begin{aligned}
& R_{m t}=\frac{I H S G_{t}-I H S G_{t-1}}{I H S G_{t-1}} \\
& E\left(R_{m}\right)=\frac{\sum_{t=1}^{n} R_{m t}}{N}
\end{aligned}
$$

Di mana:

$\mathrm{R}_{\mathrm{mt}} \quad=$ Tingkat pengembalian pasar pada bulan ke-t

$\mathrm{IHSG}_{\mathrm{t}}=$ Indeks Harga Saham Gabungan bulan ke-t

$\mathrm{IHSG}_{\mathrm{t}-1}=$ Indeks Harga Saham Gabungan bulan ke t-1

$E(R m)=$ Tingkat pengembalian rata-rata pasar yang diharapkan dalam satu bulan.

$\mathrm{N}=$ Jumlah pengamatan dalam satu tahun $(\mathrm{N}=12)$

3. Menghitung risiko masing-masing saham yang ditunjukkan oleh beta usaha $(\beta)$. Beta dihitung dengan menggunakan rumus sebagai berikut: 


$$
\begin{aligned}
\beta i= & \frac{\sigma i m}{\sigma^{2} m} \\
\sigma i m & =\frac{\sum_{t=1}^{n}\left(R_{i t}-R_{t}\right)\left(R_{m t}-R_{m}\right)}{n} \\
\sigma^{2} m & =\frac{\sum^{n}\left(R_{m t}-R_{m}\right)^{2}}{n-1}
\end{aligned}
$$

Di mana:

$\sigma i m=$ Kovarian tingkat pengembalian saham $\mathrm{i}$ dengan tingkat pengembalian pasar.

$\sigma^{2} m=$ Varian tingkat pengembalian pasar.

4. Menentukan tingkat bunga bebas risiko (Rf). Tingkat bunga bebas risiko adalah tingkat suku bunga investasi yang dapat diperoleh investor tanpa menanggung risiko. Tingkat bunga bebas risiko yang digunakan adalah tingkat suku bunga Sertifikat Bank Indonesia (SBI).

5. Menghitung biaya ekuitas atau Modal Sendiri. Rumusnya:

$$
K e=R f+\beta(R m-R f)
$$

$M R P=R m-R f$

Di mana:

$E(R)=$ Harapan pengembalian

$R f \quad=$ Tingkat pengembalian bebas risiko

$R m=$ Tingkat pengembalian atas risiko pasar

B = Faktor risiko (beta) yang berlaku untuk perusahaan

MRP = Market Premium Risk (Premi Risiko Pasar)

6. Perhitungan biaya utang, dengan rumus:

$K d=k d \times(1-t)$

Di mana:

$k d=$ Beban bunga dibagi jumlah utang jangka panjang

1- $t=$ Faktor koreksi

7. Menghitung biaya atas modal dengan metode Weighted Average Cost of Capital/ WACC. Rumusnya adalah:

$W A C C=k d(1-t) W d+K e . W e$

Di mana:

$K d=$ Biaya utang jangka panjang

$K e=$ Biaya pengembalian saham

$W d=$ Proporsi utang dalam struktur modal

We $=$ Proporsi saham dalam struktur modal

$t=$ Tingkat pajak perusahaan

8. Perhitungan NOPAT (Net Operating Profit After Tax). Rumusnya adalah:

NOPAT = Laba Bersih + Beban Bunga

Di mana:

Beban Bunga = biaya bunga yang harus dibayar oleh perusahaan.

9. Perhitungan EVA. Rumusnya:

EVA $=$ NOPAT - Biaya Modal 
Di mana:

Biaya modal $=$ WACC $x$ modal yang diinvestasikan

Kinerja keuangan perusahaan melalui EVA, untuk menentukan strategi yang dapat dijalankan agar kinerja keuangan lebih baik, dinilai dengan kriteria sebagai berikut:

1. Jika EVA $>0$, maka terjadi proses nilai tambah perusahaan, kinerja perusahaan baik. Ini bermakna laba yang tersedia mampu melebihi harapan investor, perusahaan dapat mengembalikan pinjaman kreditur serta dapat menganggarkan pemberian bonus kepada karyawan.

2. Jika $E V A=0$, maka menunjukan posisi impas perusahaan. Ini bermakna laba yang tersedia impas untuk memenuhi harapan kreditur dan investor.

3. Jika EVA < 0, hal itu berarti total modal perusahaan lebih besar daripada laba operasi setelah pajak yang diperolehnya, sehingga kinerja perusahaan tersebut tidak baik. Ini bermakna di dalam perusahaan tidak terjadi nilai tambah, laba yang tersedia tidak mampu memberikan pengembalian setimpal dengan yang ditanam investor.

\section{Hasil Penelitian}

\section{III.1 Perhitungan EVA}

Berdasarkan data bulanan harga saham periode 2007-2008 PT Multisrada memiliki beta $(\beta)$ berturut-turut 0,44 dan 0,83. Hal ini menunjukkan bahwa PT Multistrada Tbk, memiliki resiko yang lebih kecil dari resiko pasar, karena perusahaan memiliki nilai beta $(\beta)$ berturut-turut kurang dari satu.

Pada periode 2007-2008 rata-rata tingkat pengembalian pasar yang diharapkan/E(Rm) masing-masing sebesar 3,689 persen dan negatif $(5,102)$ persen. Rata-rata tingkat suku bunga SBI perbulan pada tahun 2007 dan 2008 masing-masing adalah sebesar 8,6 persen dan 9,12 persen. Dari hasil tingkat pengembalian pasar dan suku bunga SBI di atas, maka diperoleh biaya modal saham (Ke) PT Multistrada tahun 2007 dan 2008 masing-masing sebesar 6,458 persen dan negatif $(2,631)$ persen. Pada tahun 2008 biaya modal saham (Ke) memiliki nilai yang negatif, hal ini terjadi karena adanya penurunan IHSG yang tajam pada periode akhir 2008 dampak dari krisis ekonomi global.

Berdasarkan laporan keuangan perusahaan tahun 2007 dan 2008, Perusahaan memiliki persentase beban bunga terhadap hutang jangka panjang yang cenderung meningkat. Tahun 2007 perusahaan memiliki nilai nominal beban bunga sebesar Rp 36.859.349.122 atau 15,17 persen dari nilai nominal hutang. Sedangkan pada tahun 2008 nilai beban bunga meningkat menjadi Rp 47.197.622.878 atau 11,64 persen dari nilai nominal hutang.

Selama tahun 2007-2008 hutang PT Multistrada mengalami kenaikan sebesar 31 persen dari hutang sebesar Rp 242.959.855.517 pada tahun 2007 meningkat menjadi Rp 705.408.182.337 pada tahun 2008. Dari nilai beban bunga dan hutang jangka panjang di atas dapat diperoleh biaya modal hutang (Kd) Multistrada pada tahun 2007 dan 2008 masing-masing adalah 6,95 persen dan 7,80 persen. 
Perusahaan memiliki nilai rata-rata biaya modal tertimbang (WACC) selama periode 2007 dan 2008 adalah masing-masing sebesar 5,56 persen dan negatif $(0,09)$ persen. Penurunan nilai WACC ini disebabkan adanya penurunan pada biaya pengembalian saham.

Perusahaan pada tahun 2008 mengalami penurunan laba operasi bersih setelah pajak (NOPAT) sebesar 24,06 persen dari tahun sebelumnya sebesar Rp 66.063.844.905 menjadi Rp 50.171.153.806 pada tahun 2008. Penurunan ini terjadi karena laba bersih yang dimiliki perusahaan mengalami penurunan yang tinggi mencapai 90 persen dari Rp 29.204.495.783 pada tahun 2007 menjadi Rp 2.973.530.928 pada tahun 2008 .

Modal yang diinvestasikan (IC) perusahaan pada tahun 2008 mengalami peningkatan dari tahun sebelumnya sebesar 9,75 persen, dari Rp 1.524.126.473.981 pada tahun 2007 meningkat menjadi Rp 1.672.691.622.563 pada tahun 2008. Peningkatan modal ini terjadi karena adanya kenaikan yang cukup tinggi pada ekuitas perusahaan sebesar 67 persen selama periode 2007-2008.

Berdasarkan hasil analisis dari laporan keuangan, PT Multistrada Tbk pada tahun 2007 memiliki nilai EVA yang negatif (kurang dari nol) yaitu sebesar RP 18.698.277.623,57. Hal ini menunjukkan bahwa di dalam perusahaan Multistrada pada tahun 2007 tidak terjadi nilai tambah, dan kinerja keuangan perusahaan kurang baik. Nilai EVA yang negatif ini menunjukkan bahwa laba perusahaan yang tersedia tidak mampu melebihi harapan investor dan perusahaan tidak dapat mengembalikan pinjaman dari kreditur. Sedangkan pada tahun 2008 perusahaan ini memiliki nilai EVA yang positif yaitu $\mathrm{Rp} 42.698 .678 .047,70$. hal ini , menunjukkan bahwa pada tahun 2008 perusahaan mengalami peningkatan kinerja dari tahun sebelumnya. Nilai EVA yang positif ini menunjukkan adanya proses pertambahan nilai di dalam perusahaan, ini berarti laba yang dihasilkan perusahaan sudah melebihi harapan investor dan perusahaan dapat mengembalikan pinjaman kreditur serta dapat menganggarkan pemberian bonus bagi para karyawan.

Nilai EVA pada tahun 2008 meningkat tajam dari tahun sebelumnya, peningkatan ini terjadi karena biaya modal yang dimiliki perusahaan memiliki nilai negatif yang diakibatkan dari harga saham yang menurun, sehingga nilai EVA-nya bertambah. Untuk lebih jelasnya peningkatan nilai EVA dan komponennya dapat dilihat pada Gambar 1.

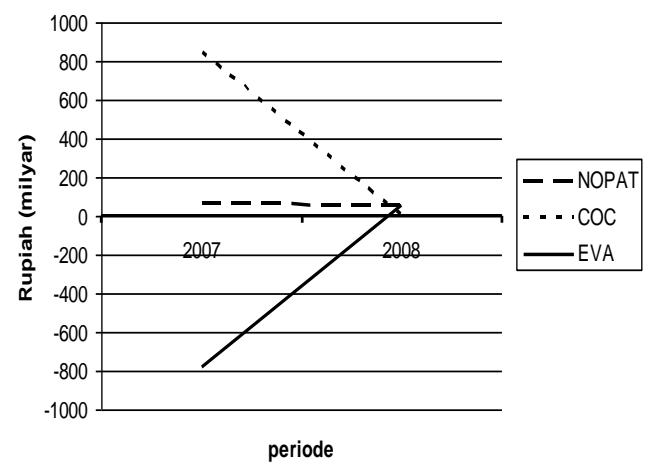

Gambar 1. Grafik NOPAT, biaya modal dan EVA PT Multistrada Arah sarana Tbk 
Nilai EVA yang negatif terjadi dikarenakan nilai NOPAT yang lebih kecil dibandingkan dengan rata-rata biaya yang harus dikeluarkan perusahaan untuk setiap modal yang dipakai. Pada periode 2007 nilai NOPAT perusahaan memiliki nilai yang negatif, sehingga berpengaruh terhadap hasil EVA yang negatif. Untuk menghasilkan EVA yang positif, perusahaan harus menghasilkan NOPAT selama periode 2007 harus lebih dari Rp 84.762.122.528,57.

Berdasarkan data bulanan harga saham periode 2007-2008 PT Gajah Tunggal memiliki beta $(\beta)$ berturut-turut 0,65 dan 1,36 . Hal ini menunjukkan bahwa PT Gajah Tunggal Tbk, pada tahun 2007 memiliki resiko yang lebih kecil dari resiko pasar, karena perusahaan memiliki nilai beta $(\beta)$ yang kurang dari satu. Sedangkan pada tahun 2008 perusahaan memiliki resiko yang lebih besar dari resiko pasar, karena memiliki nilai Beta $(\beta)$ lebih dari satu.

Pada periode 2007-2008 rata-rata tingkat pengembalian pasar yang diharapkan/E(Rm) masing-masing sebesar 3,689 persen dan negatif $(5,102)$ persen. Rata-rata tingkat suku bunga SBI perbulan pada tahun 2007 dan 2008 masing-masing adalah sebesar 8,6 persen dan 9,12 persen. Dari hasil tingkat pengembalian pasar dan suku bunga SBI diatas, diperoleh biaya modal saham (Ke) PT Multistrada tahun 2007 dan 2008 masing-masing sebesar 5,397 persen dan negatif $(10,175)$ persen. Pada tahun 2008 biaya modal saham (Ke) memiliki nilai yang negatif, hal ini terjadi karena adanya penurunan IHSG yang tajam pada periode akhir 2008 akibat terjadinya krisis ekonomi global.

Berdasarkan laporan keuangan perusahaan tahun 2007 dan 2008, Perusahaan memiliki persentase beban bunga terhadap hutang jangka panjang yang cenderung meningkat. Tahun 2007 perusahaan memiliki nilai nominal beban bunga sebesar Rp 411.503.000.000 atau 9,13 persen dari nilai nominal hutang. Sedangkan pada tahun 2008 nilai beban bunga meningkat sebesar 13 persen menjadi Rp 462.994.000.000 atau 9,27 persen dari nilai nominal hutang.

Selama tahun 2007-2008 hutang PT Gajah Tunggal mengalami kenaikan sebesar 10,74 persen dari hutang sebesar Rp 4.508.847.000.000 pada tahun 2007 meningkat menjadi Rp 4.992.913.000.000 pada tahun 2008. Dari nilai beban bunga dan hutang jangka panjang di atas dapat diperoleh biaya modal hutang (Kd) Gajah Tunggal pada tahun 2007 dan 2008 masing-masing adalah 5,91 persen dan 7,48 persen.

Perusahaan memiliki nilai rata-rata biaya modal tertimbang (WACC) selama periode 2007 dan 2008 adalah berturut-turut sebesar 4,67 persen dan 2,36 persen. Penurunan nilai WACC disebabkan adanya penurunan pada biaya pengembalian saham.

Perusahaan selama periode 2007 memiliki nilai laba operasi bersih setelah pajak (NOPAT) sebesar Rp 502.344.000.000 dengan nilai laba bersihnya sebesar Rp 90.841.000.000. Pada tahun 2008 perusahaan mengalami kerugian bersih sebesar Rp 624.788.000.000, sehingga NOPATnya pun mengalami mengalami penurunan/kerugian yang besar dari tahun sebelumnya sebesar Rp 161.794.000.000 pada akhir 2008. Kerugian dari pendapatan bersih ini dikarenakan adanya kerugian selisih kurs yang besar dampak dari krisis ekonomi global.

Modal yang di investasikan (IC) perusahaan pada tahun 2008 mengalami penurunan dari tahun sebelumnya sebesar 4,48 persen, dari Rp 6.628.959.000.000 pada tahun 2007 turun menjadi Rp 6.331.848.000.000 pada tahun 2008. Penurunan modal ini 
terjadi karena adanya penurunan pada ekuitas sebesar 30,87 persen selama periode 2007-2008.

Berdasarkan hasil analisis, PT Gajah Tunggal Tbk pada tahun 2007 memiliki nilai EVA yang positif yaitu sebesar Rp 192.512.501.327,33. Hal ini menunjukkan bahwa pada tahun 2007 di dalam perusahaan Multistrada terjadi nilai tambah, dan kinerja keuangan perusahaan baik, karena perusahaan mampu memenuhi harapan investor dan kreditur. Sedangkan pada tahun 2008 perusahaan mempunyai nilai EVA yang negatif yaitu sebesar Rp 311.345.601.825,395. Nilai EVA yang negatif menunjukkan bahwa laba perusahaan yang tersedia tidak mampu melebihi harapan investor dan perusahaan tidak dapat mengembalikan pinjaman dari kreditur.

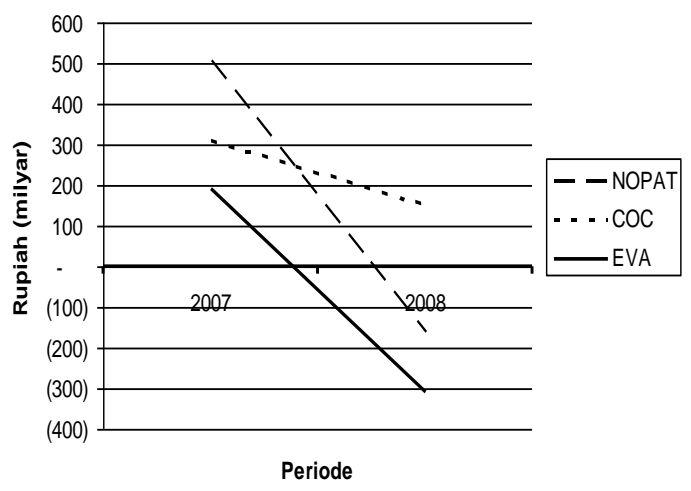

Gambar 2. Grafik NOPAT, biaya modal dan EVA PT Gajah Tunggal Tbk

Penurunan nilai EVA pada tahun 2008 ini terjadi karena adanya kerugian bersih akibat dari kerugian selisih kurs. Hal ini pula menunjukan adanya penurunan kinerja perusahaan pada tahun 2008. Penurunan nilai EVA yang di ikuti oleh NOPAT dapat dilihat pada Gambar 2.

Nilai EVA yang negatif pada tahun 2008 terjadi dikarenakan nilai NOPAT yang dihasilkan negatif dibandingkan dengan rata-rata biaya yang harus dikeluarkan perusahaan untuk setiap modal yang dipakai, sehingga berpengaruh terhadap hasil EVA yang negatif. Untuk menghasilkan EVA yang positif, perusahaan harus menghasilkan NOPAT selama periode 2008 harus lebih dari Rp 149.551.601.825,40.

\section{III.2. Ringkasan Perhitungan EVA}

Dari kedua perusahaan otomotif go publik yang dapat dilihat dari kinerja keuangan perusahaan dengan metode EVA, kedua perusahaan tersebut memiliki nilai EVA yang positif dan negatif. PT multistrada tbk, pada tahun 2007 memiliki nilai yang negatif dan pada tahun 2008 kinerja perusahaan meningkat sehingga nilai EVA nya menjadi positif. Peningkatan ini dipengaruhi oleh biaya modal yang negatif, sehingga menambah pada nilai EVA.

Berbeda dengan PT Multistrada, PT Gajah Tunggal Tbk memiliki nilai EVA positif pada tahun 2007 sebelum adanya krisis global, dan pada tahun 2008 kinerja perusahaan menurun karena nilai EVA yang dihasilkan kurang dari nol (negatif) yang artinya laba bersih perusahaan tidak mampu memenuhi harapan investor, nilai EVA yang negatif ini dikarenakan laba operasi setelah pajak (NOPAT) yang dimiliki 
perusahaan tersebut lebih kecil dari biaya modal yang dihasilkan. Dari kedua perusahaan tersebut PT Multistrada Tbk mempunyai kinerja yang baik dibandingkan dengan PT gajah tunggal, karena PT Multistrada pada tahun 2008 mengalami peningkatan nilai EVA dari tahun sebelumnya meskipun pada tahun tersebut terjadi krisis ekonomi global. Sedangkan kinerja PT Gajah Tunggal Tbk bisa dikatakan kurang baik, karena perusahaan mengalami penurunan nilai EVA yang drastis pada tahun 2008 dampak dari krisis ekonomi global. Untuk itu perusahaan perlu melakukan strategi untuk meningkatkan kinerja perusahaannya. Strategi yang bisa dilakukan untuk memperbaiki kinerjanya, perusahaan harus bisa meningkatkan laba operasi tanpa menambah modal, mengurangi kegiatan-kegiatan yang tidak menambah nilai perusahaan (activity non value added) dan menambah kegiatan-kegiatan yang menambah nilai perusahaan (activity value added).

\section{Kesimpulan}

Berdasarkan analisis kinerja keuangan dengan menggunakan metode EVA, dari dua perusahaan yang dianalisis terdapat satu perusahaan yang memiliki kinerja keuangan yang baik dengan kata lain telah memenuhi harapan investor dan kreditur serta bagi manajemen perusahaan itu sendiri yaitu PT Multistrada Tbk, karena pada tahun 2008 PT Multistrada mengalami peningkatan kinerja keuangan lebih baik dari tahun 2007 yang memiliki nilai EVA negatif meningkat menjadi positif pada tahun 2008, walaupun pada akhir tahun tersebut terjadi krisis ekonomi global. Berbeda dengan PT Multistrada, PT Gajah Tunggal Tbk memiliki penurunan kinerja pada tahun 2008. Pada tahun 2007 perusahaan memiliki nilai EVA yang positif, akan tetapi pada akhir tahun nilai EVA menurun menjadi negatif, karena adanya kerugian yang cukup besar akibat dari krisis ekonomi global.

Dengan melihat data keuangan perusahaan, PT Multistrada Tbk merupakan perusahaan yang memiliki kinerja keuangan yang baik. Hal ini dikarenakan PT Multistrada mengalami peningkatan kinerja keuangan pada tahun 2008 dan tidak terlalu terpengaruh oleh krisis ekonomi global, sehingga dapat menarik dimata para investor, dibandingkan dengan PT Gajah Tunggal Tbk yang mengalami penurunan kinerja pada tahun 2008.

\section{Daftar Pustaka}

"Kebijakan pemerintah menurunkan harga BBM tidak serta merta meningkatkan penjualan kendaraan. Beberapa kendala masih menghadang, terutama tingginya suku bunga dan pelemahan rupiah. Saham sektor otomotif pun terancam muram" http://inilah.com, [09 januari 2009].

Keown, A. J . 2004. Manajemen Keuangan: prinsip-prinsip dan aplikasi. Edisi 9. PT Indeks Kelompok Gramedia, Jakarta.

Nazir, M. 2005. Metode Penelitian. Ghalia: Jakarta.

Ningrum, A P. 2008. Analisis Kinerja Keuangan Perusahaan Telekomunikasi Go Publik dengan Metode Eonomic Value Added (EVA). Skripsi pada Departemen Manajemen, Fakultas Ekonomi dan Manajemen, Institut Pertanian Bogor, Bogor. 
Nordiawan, D. 2006. Akuntansi Sektor Publik. Salemba Empat. Jakarta

[PT Gajah Tunggal Tbk]. 2009. Laporan Keuangan Konsolidasi dan Informasi Tambahan untuk Tahun-Tahun yang Berakhir 31 Desember 2008 dan 2007 dan Laporan Auditor. Bursa Efek Indonesia, Jakarta.

[PT Multistrada Arah Sarana Tbk]. 2009. Laporan Keuangan Beserta Laporan Auditor Independen 31 Desember 2008 dan 2007 dan Laporan Auditor. Bursa Efek Indonesia, Jakarta

Sartono, A. 1997. Manajemen Keuangan. Edisi 3. BPFE:Yogyakarta.

Supiani, D. 2005. Analisis Kinerja Keuangan dengan Metode Eonomic Value Added (EVA) (Studi Kasus pada BUMN Go Public). Skripsi pada Departemen Manajemen, Fakultas Ekonomi dan Manajemen, Institut Pertanian Bogor, Bogor.

Tunggal, A W. 2008. Memahami Economic Value Added (EVA) teori, soal dan kasus. Harvarindo. Jakarta.

Utomo, L L. 1999. Economic Value Added Sebagai Ukuran Keberhasilan Kinerja Manajemen Perusahaan: Jurnal Akuntansi dan Keuangan Vol 1 No 1.

http://puslit.petra.ac.id/journals/accounting/.[Februari 2009]

Weston, J.F. dan E, Thomas. 1990. Manajemen Keuangan. Edisi Kedelapan. Erlangga: Jakarta.

Widyakusuma, R. 2007. Pengaruh Economic Value Added, Residual Income, Operating Cashflow dan Operating Income Terhadap Return Saham (Studi empiris pada perusahaan manufaktur dan perbankan Bursa Efek Jakarta 2004-2006). Skripsi pada Program Akuntansi, Fakultas Ekonomika dan Bisnis, Universitas Gadjah Mada, Yogyakarta.

Wikipedia. Industri Otomotif. http//id.wikipedia.org// Industri otomotif.htm. [Januari 2009].

www.idx.co.id. 2009. Perusahaan Otomotif

Young, S. D and S. E. O'byrne. 2001. EVA dan Manajemen Berdasarkan Nilai: Panduan Praktis untuk Implementasi. Salemba Empat. Jakarta. 